\title{
IMPLEMENTASI PROGRAM ARSIP MASUK DESA
}

\author{
Drs. Burhanudin Dwi Rohmatun \\ Arsiparis Badan Perpustakaan dan Arsip Daerah DIY
}

\section{INTISARI}

Program Arsip Masuk Desa (AMD) merupakan program yang dicanangkan oleh ANRI sejak tahun 2009. Tujuan Program AMD adalah meningkatkan peran arsip dalam penyelenggaraan administrasi pemerintah desa dalam rangka meningkatkan pelayanan kepada masyarakat di desa. Sasaran Program AMD adalah meningkatnya kualitas pengelolaan arsip pada pemerintah desa yang sesuai dengan kaidah kearsipan dan peraturan perundang-undangan.

Materi kearsipan yang disampaikan dalam Program AMD meliputi Pembuatan Naskah Dinas, Pengurusan Surat, Penataan dan Penggunaan Arsip, serta Penyusutan Arsip. Adapun lingkup yang menjadi obyek AMD adalah arsip yang tercipta pada Pemerintah Desa/ Kelurahan, Badan Permusyawaratan Desa (BPD), dan Kelurahan. Kendala yang dihadapi dalam implementasi Program AMD bersumber pada ketidakmerataan potensi, kondisi, dan sumber daya, antara lain kesenjangan antar desa yang dimiliki Pemerintah Desa di bidang anggaran, SDM, dan perbedaan sosial budaya. Alternatif solusi yang dapat dilaksanakan dalam implementasi Program AMD antara lain perumusan konsep yang jelas, pemetaan kondisi dan sumber daya desa, serta penyiapan SDM dan anggaran.

Kata kunci: arsip, arsip masuk desa

\begin{abstract}
The Village Archives Program (Arsip Masuk Desa/AMD) is a program launched by ANRI since 2009. The objective of AMD Program is to increase the role of archives in administering village government administration in order to improve services to the village community. AMD Program targets are the increasing quality of archival management in village government in accordance with archival rules and legislation.

Archival courses presented in the AMD Program includes the Making of Official Scripts, Letters Management, Arrangement and Use of Archives, and Disposal of Archives. The scope that became the object of AMD is the archive created in the Village Government, Village Consultative Board (Badan Permusyawaratan Desa/BPD), and Kelurahan. The obstacles faced in the implementation of the AMD Program stem from the inequalities of potential, conditions, and resources, including village-to-village gaps in the areas of budget and human resources, and socio-cultural differences. Alternative solutions that can be implemented in the implementation of the AMD Program include the formulation of a clear concept, mapping the condition and resources of the village, as well as the preparation of human resources and budget.
\end{abstract}

Keywords: archives, village entrance archives 


\section{PENGANTAR}

Dalam rencana pembangunan nasional jangka panjang maupun rencana pembangunan jangka menengah, pembangunan kearsipan menjadi salah satu bidang pembangunan nasional dalam aspek perbaikan tata kelola pemerintahan, khususnya pengembangan sistem ketatalaksanaan untuk mendukung peningkatan efisiensi, transparansi, dan akuntabilitas dalam proses kerja pemerintahan. Peningkatan efisiensi, transaparansi, dan akuntabilitas dalam proses kerja pemerintahan merupakan amanat sebagaimana tercantum dalam Undang-Undang Republik Indonesia Nomor 17 Tahun 2007 tentang Rencana Pembangunan Jangka Panjang Nasional (RPJPN) 20052025 dan Peraturan Presiden Nomor 05 Tahun 2010 tentang Rencana Pembangunan Jangka Menengah Nasional (RPJMN) 2010-2014 (Fadhilah, Khoerun Nisa, 2012).

Dalam pelaksanaan pembangunan nasional, termasuk bidang kearsipan, aktor utama pembangunan adalah manusia. Demikian juga dalam membangun sistem kearsipan melalui Program Arsip Masuk Desa (AMD). Oleh karena itu, human capital merupakan modal utama pelaksanaan pembangunan, baik fisik maupun nonfisik. Ada beberapa aspek yang dapat diambil dari upaya membangun human capital dalam rangka Arsip Masuk Desa. Dari pendapat Laura W. Perna a, Kata Orosz, dan Zakir Jumakulov ada salah satu aspek yang dapat diambil dalam pembangunan kearsipan adalah Integration of new knowledge into the prevailing culture (Zakir Jumakulov, Laura W. Perna, Kata Orosz, 27-1-2017). Hal ini disebabkan membangun kearsipan di Indonesia, termasuk melalui program AMD, adalah menawarkan dua sisi yaitu ilmu pengetahuan dan perubahan kultur. Arsip Masuk Desa (AMD) tentu bukan program yang bersifat latah. Kalaupun sebutannya menyerupai AMD (ABRI Masuk Desa) di era orde baru, tentu hal itu sebagai suatu kebetulan. Akan tetapi jelas keduanya memiliki perbedaan yang sangat jauh. Istilahnya saja yang samasama menggunakan kosa kata 'masuk desa'.

ABRI Masuk Desa berangkat dari konsep Dwi Fungsi ABRI, terlepas dari aroma politik yang menjadi muatan AMD-nya 'prajurit' yang jelas saat itu terkonsep sebagai upaya pemberdayaan tentara dan masyarakat desa dalam suatu kebersamaan yang disebut dengan istilah "ABRI Manunggal dengan rakyat". Tentara tidak hanya menempa diri di camp pelatihan dan barak militer, tetapi sekaligus mengupayakan untuk mengeliminasi kemiskinan dan 'ketertinggalan desa'. Sudah tentu selain hal tersebut merupakan upaya memajukan desa juga merupakan pembinaan teritorial.

Meskipun bidang garapannya di daerah pedesaan, AMD berangkat dengan konsep yang berbeda dengan AMD milik tentara. Kalau ABRI Masuk Desa lebih berhubungan dengan masyarakat desa secara langsung, Arsip Masuk Desa memiliki cakupan yang lebih terbatas. Tentara masuk desa lebih cenderung pada upaya menggerakkan masyarakat untuk membangun desa dalam berbagai bidang, terutama masalah yang terkait dengan hal-hal yang bersifat fisik. Adapun Arsip Masuk Desa lebih menekankan cara menciptakan tertib arsip di kantor pemerintah desa. Artinya, untuk arsip masuk desa memiliki cakupan yang terbatas pada lingkup pemerintah desa. Walaupun bukan berarti hal tersebut hanya untuk kepentingan pemerintah desa tetapi secara hakiki juga menyangkut kepentingan masyarakat desa. Dalam konteks ini masyarakat tidak secara langsung dilibatkan untuk membenahi tata kearsipan di lingkungan pemerintah desa. 
Hal yang harus dipahami adalah bahwa dalam Program ABRI Masuk Desa secara riil anggota tentara datang ke desa untuk bekerja membangun desa bersama-sama dengan masyarakat. Bukan berarti Arsip Masuk Desa adalah datangnya berkarung-karung arsip dari kota ke desa. Arsip Masuk Desa juga bukan berarti bahwa di desa tidak ada arsip. Bukan pula berarti di desa belum ada sistem kearsipan yang dilaksanakan oleh pemerintah desa. Sesederhana apapun di desa pasti sudah ada arsip, dan juga ada sistem yang digunakan untuk mengelola arsip tersebut. Oleh karena itu, harus dipahami bahwa dalam konteks ini yang dimaksud dengan Arsip Masuk Desa adalah upaya untuk meningkatkan peran arsip dalam kehidupan berbangsa dan bernegara pada umumnya dan penyelenggaraan administrasi pemerintahan desa pada khususnya dalam rangka peningkatan pelayanan prima kepada masyarakat.

Pertanyaan yang muncul kemudian adalah kenapa harus ada program Arsip Masuk Desa (AMD)? Pertanyaan ini tidak hanya sekedar dengan mengajukan standar normatif apa tujuan Arsip Masuk Desa sebagaimana yang tertuang dalam Peraturan Kepala Arsip Nasional RI Nomor 08 Tahun 2009 tentang Program Arsip Masuk Desa. Perka tersebut menyatakan tujuan AMD sebagai upaya untuk meningkatkan peran arsip desa untuk peningkatan pelayanan prima pada masyarakat. Lebih dari itu mesti berpijak pada permasalahan yang muncul dalam pengelolaan arsip secara nasional, lebih khususnya di desa.

Seperti telah diketahui bahwa secara umum pengelolaan arsip di Indonesia masih jauh dari kondisi ideal. Pengelolaan arsip yang selama ini dilaksanakan masih jauh dari kemungkinan tersedianya arsip secara cepat, tepat, dan lengkap. Hal ini berarti masih jauh juga dari kondisi yang mampu menjamin keselamatan arsip. Pelaksanaan tata kearsipan masih jauh dari tujuan kondisi ideal yaitu sebagai suatu sistem yang komprehensif dan terpadu, namun juga untuk menjamin perlindungan kepentingan negara dan hak-hak keperdataan rakyat.

Hal yang perlu dipahami adalah bahwa desa merupakan ujung tombak dalam kehidupan bernegara. Dikatakan demikian karena desa merupakan pemerintah yang langsung berhadapan dengan rakyat. Dalam kaitannya dengan layanan masyarakat, dituntut kehatihatian. Saat ini dalam setiap transaksi yang secara langsung berhubungan dengan masyarakat harus disertai bukti secara transparan. Kehidupan modern menuntut alat-alat bukti intelektual yang dapat memahami lingkungan secara mendalam dan penuh arti sehingga tidak terikat dan terpaku pada rasa kekinian (Soedjatmoko, 1980: 28). Ketertiban desa akan memberi kontribusi positif bagi ketertiban pengelolaan negara secara keseluruhan. Oleh karena itu, sekalipun Arsip Masuk Desa lebih ditujukan kepada pemerintah desa tetapi memiliki dampak terhadap perkembangan masyarakat desa pada umumnya. Logika ini didasarkan pada tuntutan kondisi yang menuntut akuntabilitas aparat desa dalam melaksanakan tugas layanan pada masyarakat.

Pertimbangan lain adalah bahwa kegiatan pemerintahan desa dapat dikatakan sebagai pemerintahan daerah 'otonomi tingkat III”. Istilah 'daerah tingkat III’ memang tidak dikenal dalam tata kenegaraan Indonesia tetapi secara riil desa merupakan suatu pemerintahan yang memiliki otonomi untuk mengatur rumah tangganya sendiri. Desa memiliki otonomi untuk mengelola keuangan, baik belanja maupun pendapatan. Pemerintahan desa juga memiliki Badan Perwakilan Desa (BPD) yang merupakan lembaga 'legislatif' desa. Mengingat arti penting arsip mestinya desa harus mampu mengakomodasikan berbagai kepentingan yang timbul di masyarakat, 
sebab hal yang fundamental dalam penyelenggaraan negara adalah adanya kemampuan institusi penyelenggara negara untuk dapat secara maksimal mengakomodasi kepentingan masyarakat (Ashiddiqie, Jimly, 2010: v).

Sekalipun tidak sama dengan pemerintahan desa, kantor lurah di perkotaan juga memiliki fungsi sama, yaitu sebagai ujung tombak yang langsung berhadapan dengan rakyat. Kantor lurah, dan juga kalurahan tidak memiliki otonomi sebagaimana desa. Akan tetapi sebagai lembaga yang berhadapan langsung dengan masyarakat dalam hal layanan, kantor lurah memiliki tingkat risiko yang tidak jauh berbeda dengan pemerintahan desa. Apabila pemerintahan desa berhadapan dengan masyarakat yang relatif bersahaja, kantor lurah berhadapan dengan masyarakat yang kritis dengan permasalahan yang jauh lebih kompleks dibanding dengan permasalahan masyarakat desa. Harus menjadi pemahaman bersama bahwa sampai saat ini, banyak persoalan yang melingkupi birokrasi pemerintahan, khususnya dalam bidang pelayanan publik (Simamora, Janpatar, 2013).

Sebagai suatu lembaga yang memiliki risiko 'tertekan' dari atas dan dari bawah, bukti-bukti rekaman kegiatan pemerintahan desa maupun kalurahan sewajarnya untuk dikelola dengan sebaik-baiknya. Kecerobohan dalam pengelolaan arsip di desa maupun kelurahan berarti menimbun potensi terjadinya konflik di masa yang akan datang. Dalam hal ini secara teoritis kantor desa, sebagai perwujudan dari lembaga publik di era modern dituntut adanya pengelolaan arsip secara modern pula. Hal ini disebabkan kehidupan modern menuntut kecepatan informasi. Bagi sebuah organisasi informasi merupakan salah satu sumber data yang memiliki peran strategis (Sugiarto, Agus dan Teguh Wahyono, 2005: 7-8). Boone menyebut informasi sebagai "data relevant to the manager in making decision” (Boone, Louis E, 1984: 453). Arsip merupakan salah satu sumber informasi. Apalagi tingkat pendidikan serta tingkat sensitibilitas masyarakat ada kecenderungan semakin meningkat.

Pemahaman tentang arsip perlu disamakan. Hal ini penting karena secara umum, permasalahan yang menimpa suatu negara boleh jadi bermula dari penggunaan istilah-istilah administrasi pemerintahan negara yang tidak jelas, rancu, ambivalen, multitafsir atau kontradiktif (Sudrajat, Tatang, 2016). Selama ini secara awam arsip hanya dipahami sebatas pertinggal, surat yang sudah purna pakai, atau dipahami juga sebatas pertinggal surat yang dikirim.

\section{Rumusan Masalah}

Berdasarkan uraian tersebut dapat dirumuskan permasalahan sebagai berikut: Bagaimanakah pelaksanaan Program AMD, kendala apa saja yang muncul dan alternatif apa yang ditawarkan agar program ini dapat berjalan?

Tulisan ini berusaha menganalisis salah satu program nasional yang terkait dengan bidang administrasi publik. Sebagai bidang yang tidak memiliki 'popularitas' yang cukup memadai, Program AMD tentu memiliki permasalahan yang sangat dimungkinkan tidak terakomodasi oleh para penggagasnya. Apalagi apabila program ini hanya 'numpang' popularitas ABRI Masuk Desa, Koran Masuk Desa, atau program lain yang pernah ada pada zaman orde baru.

\section{KERANGKA PEMIKIRAN Gambaran tentang Desa}

Desa dapat dipahami sebagai desa sebagai suatu kesatuan hukum dan di dalamnya bertempat tinggal sekelompok masyarakat yang berkuasa mengadakan pemerintahan sendiri. Istilah desa merupakan pembagian wilayah 
administratif di Indonesia yang dipimpin oleh seorang kepala desa (Sasrawan, Hedi, 20-01-2017). Sebuah desa merupakan kumpulan dari beberapa unit pemukiman kecil yang disebut kampung (Banten, Jawa Barat) atau dusun (Yogyakarta) atau banjar (Bali) atau jorong (Sumatera Barat). Kepala Desa dapat disebut dengan nama lain misalnya Kepala Kampung atau Petinggi di Kalimantan Timur, Pambakal di Kalimantan Selatan, Hukum Tua di Sulawesi Utara, Lurah Desa (Yogyakarta).

Sejak berlaku otonomi daerah istilah desa dapat disebut dengan nama lain, misalnya di Sumatera Barat disebut dengan istilah nagari, dan di Papua dan Kutai Barat, Kalimantan Timur disebut dengan istilah kampung (https://id.wikipedia.org/wiki/Desa, 201-2017). Begitu pula segala istilah dan institusi di desa dapat disebut dengan nama lain sesuai dengan karakteristik adat istiadat desa tersebut. Hal ini merupakan salah satu pengakuan dan penghormatan terhadap asal-usul dan adat istiadat setempat sesuai dengan ketentuan Undang-Undang Dasar 1945.

Beberapa ahli memberikan pengertian desa yang berbeda-beda tetapi dari berbagai pengertian tersebut sebenarnya memiliki benang merah yang sama. R. Bintarto memberi pengertian desa sebagai perwujudan geografis yang ditimbulkan oleh unsur-unsur fisiografis, sosial, ekonomis politik, kultural setempat dalam hubungan dan pengaruh timbal balik dengan daerah lain. Sutarjo Kartohadikusumo menyatakan desa merupakan kesatuan hukum tempat tinggal suatu masyarakat yang berhak menyelenggarakan rumah tangganya sendiri merupakan pemerintahan terendah di bawah camat. Adapun William Ogburn dan MF Nimkoff menyebutkan bahwa Desa adalah kesatuan organisasi kehidupan sosial di dalam daerah terbatas. Misra memberi batasan desa sebagai suatu kumpulan tempat tinggal dan kumpulan daerah pertanian dengan batas-batas tertentu yang luasnya antara $50-1.000$ are." Menurut Paul H Landis, desa adalah suatu wilayah yang jumlah penduduknya kurang dari 2.500 jiwa dengan ciri-ciri sebagai berikut (Fergiyono, Nico, 21-12017):

1. Mempunyai pergaulan hidup yang saling kenal mengenal antra ribuan jiwa;

2. Ada pertalian perasaan yang sama tentang kesukuaan terhadap kebiasaan;

3. Cara berusaha (ekonomi) aalah agraris yang paling umum yang sangat dipengaruhi alam sekitar seperti iklim, keadaan alam, kekayaan alam, sedangkan pekerjaan yang bukan agraris adalah bersifat sambilan.

Secara legal formal sebagaimana disebutkan di dalam Undang-Undang Nomor 32 tahun 1999 menyatakan desa adalah kesatuan masyarakat hukum yang memiliki kewenangan untuk mengatur dan mengurus kepentingan masyarakat setempat berdasarkan asal-usul dan adat istiadat setempat yang diakui dalam sistem pemerintahan Nasional dan berada di daerah Kabupaten. Menurut Peraturan Pemerintah Nomor 72 Tahun 2005 tentang Desa, disebut bahwa desa adalah kesatuan masyarakat hukum yang memiliki batas-batas wilayah yang berwenang untuk mengatur dan mengurus kepentingan masyarakat setempat, berdasarkan asal-usul dan adat istiadat setempat yang diakui dan dihormati dalam sistem Pemerintahan Negara Kesatuan Republik Indonesia.

Desa bukan bawahan kecamatan, karena kecamatan merupakan bagian dari perangkat daerah kabupaten/kota, dan desa bukan merupakan bagian dari perangkat daerah. Berbeda dengan Kelurahan, Desa memiliki hak mengatur wilayahnya lebih luas, termasuk kewenangan dalam mengelola keuangan. Kepala Desa, yang di juga disebut lurah 
desa bukan staf dari camat, tetapi pejabat publik yang dipilih secara langsung oleh rakyat. Dalam perkembangannya, desa dapat diubah statusnya menjadi kelurahan. Adapun Kewenangan desa meliputi :

1. Menyelenggarakan urusan pemerintahan yang sudah ada berdasarkan hak asal usul desa;

2. Menyelenggarakan urusan pemerintahan yang menjadi kewenangan kabupaten/kota yang diserahkan pengaturannya kepada desa, yakni urusan pemerintahan yang secara langsung dapat meningkatkan pelayanan masyarakat;

3. Tugas pembantuan dari Pemerintah, Pemerintah Provinsi, dan Pemerintah Kabupaten/Kota;

4. Urusan pemerintahan lainnya yang diserahkan kepada desa.

Dalam pelaksanaan pemerintahan desa, lurah desa dibantu perangkat desa. Perangkat Desa terdiri dari Sekretaris Desa, yang di Yogyakarta disebut carik, dan Perangkat Desa lainnya. Sekretaris Desa, sebagian mulai dijabat oleh Pegawai Negeri Sipil, atau dengan mekanisme pengakatan sekretaris desayang memenuhi syarat menjadi Pegawai Sipil. Sekretaris Desa diangkat oleh Sekretaris Daerah Kabupaten/Kota atas nama Bupati/Walikota. Selain sekretaris desa lurah desa juga dibantu Perangkat Desa lainnya yang diangkat oleh Kepala Desa dari penduduk desa yang ditetapkan dengan Keputusan Kepala Desa. Perangkat desa juga mempunyai tugas untuk melayani dan mengayomi kepentingan masyarakat di wilayahnya.

Desa juga memiliki lembaga Badan Permusyawaratan Desa (BPD) yang merupakan perwujudan demokrasi dalam penyelenggaraan pemerintahan desa. Lembaga ini merupakan lembaga 'legislatifnya' desa. Anggota BPD adalah wakil dari penduduk desa bersangkutan berdasarkan keterwakilan wilayah. Pimpinan dan Anggota BPD tidak diperbolehkan merangkap jabatan sebagai Kepala Desa dan Perangkat Desa. BPD berfungsi menetapkan Peraturan Desa bersama Kepala Desa, menampung dan menyalurkan aspirasi masyarakat.

Penyelenggaraan urusan pemerintahan desa yang menjadi kewenangan desa didanai dari Anggaran Pendapatan dan Belanja Desa (APB Desa), bantuan pemerintah, dan bantuan pemerintah daerah. Penyelenggaraan urusan pemerintah daerah yang diselenggarakan oleh pemerintah desa didanai dari APBD. Sumber pendapatan desa terdiri atas: 1) Pendapatan Asli Desa, antara lain terdiri dari hasil usaha desa, hasil kekayaan desa (seperti tanah kas desa, pasar desa, bangunan desa), hasil swadaya, dan partisipasi, hasil gotong royong; 2) Bagi hasil Pajak Daerah Kabupaten/Kota; 3) Bagian dari Dana Perimbangan Keuangan Pusat dan Daerah; 4) Bantuan keuangan dari Pemerintah, Pemerintah Provinsi, dan Pemerintah Kabupaten/Kota dalam rangka pelaksanaan urusan pemerintahan; 5) Hibah dan sumbangan dari pihak ketiga yang tidak mengikat; dan 6) Pinjaman desa. Adapun APB Desa terdiri atas bagian Pendapatan Desa, Belanja Desa dan Pembiayaan. Rancangan APB Desa dibahas dalam musyawarah perencanaan pembangunan desa. Kepala Desa bersama BPD menetapkan APB Desa setiap tahun dengan Peraturan Desa.

\section{Arsip yang Tercipta di Desa}

Untuk lebih memberikan gambaran tentang arsip perlu untuk dikemukakan hal-hal yang berkaitan dengan pengertian arsip. Dari berbagai referensi dapat ditarik pengertian bahwa arsip merupakan informasi yang terekam (recorded information). International Council on Archives (ICA) menyebutkan: 
"Recorded information documen(s) regardless or form of medium created received and maintened by an agency, institution, organization, or individual in pursuancement of its legal obligations or in the transaction of business"

Bidang kearsipan merupakan bidang yang sebenarnya lahir seiring dengan dikenalnya sistem administrasi tertulis. Demikian halnya dengan orang yang mengelola arsip. Sejak awal munculnya arsip, bidang ini lebih akrab dengan dunia pemerintahan. Hal ini dirunut dari asal kata arsip itu sendiri. Secara etimologis istilah arsip berasal dari bahasa yunani "arche" yang berarti "permulaan", menjadi "ta archia" selanjutnya menjadi "archeon" yang berarti "gedung pemerintahan", dan kemudian dalam bahasa latinnya berbunyi “archivium”. (Martono, Budi, 1994: 9)

Arsiparis Belanda, S. Muller (18481922) dan R.Fruin (1857-1955) dalam bukunya yang berjudul Handleiding Voor het Ordenen en Beschrijiven van Archiven diterbitkan tahun 1898 yang kemudian diterjemahkan dalam Bahasa Inggris oleh arsiparis Amerika, Arthur $\mathrm{H}$. Leavitt, dengan judul Manual for Arrangement and Description of Archives (1940). Kata “archief” diartikan segenap dokumen tertulis, gambar dan badan cetakan yang secara resmi diterima atau dihasilkan oleh suatu badan administrasi atau oleh salah seorang pejabatnya dan sebegitu jauh dokumendokumen ini dimaksudkan untuk tetap berada dalam pemeliharaan badan-badan atau pejabat yang bersangkutan.

Sir Hilary Jenkinson dalam bukunya A Manual of Archives Administration (Oxford 1922), archives diartikan sebagai dokumen yang disusun atau digunakan selama transaksi administratif dan eksekutif (pemerintah ataupun swasta) yang membentuk sebagian, dan kemudian dipelihara di tempat pemeliharaan guna memenuhi kebutuhan informasi oleh orang-orang yang bertanggung jawab atas transaksi itu dan penggantinya yang sah.

Penyelenggaraan pemerintahan desa merupakan kegiatan pemerintahan paling bawah. Walaupun demikian permasalahan tidak jauh berbeda dengan penyelenggaraan pada tataran yang lebih tinggi. Perbedaan terletak pada tingkat kompleksitas serta bobot permasalahannya. Hal yang menjadikan pemerintahan desa menjadi cukup strategis adalah karena langsung berhadapan dengan rakyat. Napas kehidupan pemerintahan desa dengan mudah akan tercium oleh rakyat desa. Setiap gerak kepala desa beserta perangkatnya akan selalu dalam pengawasan rakyatnya. Hal yang menguntungkan bagi aparatur desa adalah karena rakyat menempatkan mereka sebagai tokoh yang mendapat kesetiaan dan penghormatan yang cukup tinggi dari rakyatnya.

Ragam permasalahan di desa akan mempengaruhi ragam informasi dari arsip yang tercipta. Berbagai permasalahan yang dihadapi pemerintahan desa, baik yang tercermin dari program kerja maupun yang muncul di masyarakat, di-cover oleh beberapa bidang. Secara umum pemerintahan desa dibagi menjadi Bagian Pemerintahan, Bagian Kesejahteraan Rakyat, Bagian Pembangunan, dan Bagian keuangan. Di luar empat bagian tersebut adalah kepala desa dan sekretaris desa atau carik. Beberapa arsip yang tercipta antara lain:

1. Arsip korespondensi

Arsip yang termasuk dalam klasifikasi arsip ini adalah arsip yang tercipta akibat adanya kegiatan surat menyurat, baik dengan instansi pemerintah, perusahaan, organisasi swasta, maupun perorangan.

2. Arsip Keuangan

Arsip keuangan merupakan arsip yang tercipta sebagai akibat adanya transaksi keuangan. Ada dua macam 
arsip keuangan, yaitu arsip korespondensi keuangan dan arsip administrasi keuangan.

3. Arsip Tanah

Arsip tanah adalah arsip yang berkaitan dengan masalah tanah. Bukan hanya menyangkut tanah kas desa tetapi juga tanah dari rakyat desa setempat. Arsip ini merupakan arsip vital desa. Dikatakan demikian karena desa memiliki otoritas dalam kaitannya dengan masalah tanah. Jual, beli, sewa, pewarisan, dan sebagainya sepanjang itu terkait dengan tanah menjadi urusan pemerintah desa.

Dilihat dari bentuk medianya, arsip pemerintah desa didominasi oleh arsip dengan media kertas. Arsip dalam bentuk lain, seperti foto maupun produk teknologi informasi merupakan arsip yang masih cukup langka, terkecuali untuk desa-desa yang berada di daerah perkotaan.

\section{PEMBAHASAN}

\section{Pelaksanaan Program AMD}

Gambaran pelaksanaan program AMD yang telah digulirkan oleh pemerintah dapat dilihat dari konsep AMD, materi yang disampaikan, penyelenggaraan pemerintahan desa, dan kondisi desa sebagai objek AMD.

\section{Konsep Program AMD}

Arsip masuk Desa merupakan suatu langkah strategis yang memiliki arti penting bagi upaya tertib administrasi. Dinamika masyarakat yang memiliki kecenderungan semakin kritis, semakin membutuhkan bukti-bukti yang bersifat resmi. Tuntutan ini salah satunya hanya dapat ditempuh dengan adanya tertib arsip.

Masyarakat desa diasumsikan sebagai masyarakat yang bersahaja, penuh nilai kekeluargaan, dan kegotongroyongan. Di sisi lain, masyarakat desa juga diasumsikan sebagai masyarakat yang belum memiliki manajemen administrasi yang sesuai dengan tuntutan masyarakat modern. Transaksi dalam berbagai kehidupan, termasuk dalam urusan pembangunan dan pemerintahan, dilakukan tanpa disertai adanya kelengkapan administrasi yang memadai. Banyak hal yang dilaksanakan hanya didasarkan pada azas kepercayaan dan kekeluargaan.

Program AMD dimaksudkan sebagai suatu langkah besar menuju perbaikan administrasi pemerintahan di lapis paling depan yang secara langsung dengan masyarakat. Program pemerintah melalui Arsip Nasional RI (ANRI) ini dilaksanakan dengan standar kearsipan yang cukup memberikan kemudahan dan keselamatan arsip dalam penyelenggaraan pemerintahan dan pembangunan.

Berdasarkan Perka ANRI Nomor 8 Tahun 2009 tentang Program AMD, tujuannya adalah meningkatkan peran arsip dalam penyelenggaraan administrasi pemerintah desa salam rangka meningkatkan pelayanan kepada masyarakat di desa. Sasaran Program AMD adalah meningkatnya pengelolaan arsip pada pemerintah desa yang sesuai dengan kaidah kearsipan dan peraturan perundang-undangan. Ruang lingkup kegiatan Program AMD meliputi:

1. Sosialiasi kearsipan kepada Lembaga Kearsipan Daerah tingkat provinsi dan kabupaten;

2. Penyusunan pedoman umum pengelolaan arsip pemerintah desa;

3. Pembangunan aplikasi pengelolaan arsip pemerintah desa;

4. Diklat pengajar kearsipan (TOT) dan diklat teknis pengelolaan arsip bagi sekretaris desa;

5. Bimbingan teknis kearsipan bagi perangkat desa;

6. Implementasi pengelolaan arsip pemerintah desa; dan

7. Evaluasi. 
Sedangkan Output yang diharapkan dalam pelaksanaan Program AMD adalah:

1. Terwujudnya perangkat desa yang memahami tentang pentingnya arsip;

2. Tersusunnya pedoman pengelolaan arsip pemerintah desa;

3. Terbangunnya aplikasi pengelolaan arsip pemerintah desa;

4. Tersedianya infrastruktur yang handal dalam rangka mendukung program arsip desa; dan

5. Tersedianya perangkat desa yang mampu mengelola arsip pemerintah desa.

Outcome yang diharapkan dalam implementasi Program AMD adalah:

1. Terselenggaranya pemerintah desa yang baik, bersih dan akuntabel;

2. Terwujudnya tata kearsipan desa yang baik dan benar;

3. Terwujudnya peningkatan pelayanan berbasis arsip kepada masyarakat;

4. Terjaminnya akurasi data yang berbasis masyarakat desa untuk memenuhi kebutuhan masyarakat; dan

5. Terlestarikannya arsip-arsip yang memiliki pertangggungjawaban nasional.

\section{Materi Arsip Masuk Desa}

Materi kearsipan yang disampaikan dalam berbagai kegiatan Program AMD adalah sebagai berikut:

1. Tata Naskah Dinas

Materi tata naskah dinas merupakan materi yang membahas bagaimana naskah dinas dibuat. Materi ini didasarkan pada Keputusan Menteri Dalam Negeri Nomor 3 Tahun 2005 tentang Tata Naskah Dinas di Lingkungan Kabupaten/Kota. Terkait dengan jenis dan format naskah dinas didasarkan pada Peraturan Menteri Negara Pendayagunaan Aparatur Negara Nomor 22 Tahun 2008 tentang Pedoman Umum Tata Naskah Dinas. Materi ini juga membahas mengenai: 1) Penyusunan naskah dinas (penyusunan naskah dinas, pengklasifikasian naskah dinas, penggandaan, sarana kelengkapan naskah dinas, dan pengetikan); 2) Penggunaan lambang dan stempel; 3) Kewenangan dan pelimpahan wewenang penandatangan naskah dinas.

2. Pengurusan Naskah Dinas

Pada materi pengurusan naskah dinas dibahas mengenai pengendalian naskah dinas masuk dan keluar. Materi ini meliputi: 1) Asas dan tanggung jawab pengurusan naskah dinas; 2) Prosedur pengurusan naskah dinas yang meliputi penerimaan, pencatatan, pengendalian, dan pendistribusian naskah dinas, baik terhadap naskah dinas masuk dan naskah dinas keluar di unit kearsipan dan unit pengolah.

3. Penataan dan Penggunaan Arsip

Materi Penataan dan penggunaan arsip dibahas mengenai peralatan, penataan berkas, dan temu balik arsip.

a. Peralatan

Dalam pelaksanaan penataan berkas membutuhkan peralatan yang secara khusus dirancang untuk membantu dalam penyimpanan dan penemuan kembali arsip. Peralatan yang dimaksud adalah peralatan yang tidak sekedar menyimpan arsip dan mempermudah penyimpanan maupun penemuan kembali, tetapi aman bagi keselamatan fisik arsip.

b. Prosedur Penataan Berkas Sebelum dilakukan penataan, arsip yang ada harus dikelompokkan dalam bentuk berkas. Penyimpanan tidak dilakukan per item tetapi 
setidaknya per berkas (file). Ada beberapa bentuk berkas, yaitu yang didasarkan pada kegiatan (biasanya untuk arsip hasil surat menyurat/surat masuk keluar yang ditimbulkan dari kegiatan dari instansi), berkas berdasarkan kesamaan perihal (biasanya arsip hasil surat menyurat yang ditimbulkan dari kegiatan instansi lain, atau arsip yang tumbuh secara rutin di instansi itu sendiri seperti cuti, usul kenaikan pangkat dsb.), berdasarkan jenis (untuk produk peraturan perundang-undangan), dan file pegawai.

Dalam kegiatan penataan berkas harus dilakukan dengan prosedur pemberkasan yang benar dan dilaksanakan secara konsisten. Hal ini akan menentukan kualitas dari penataan berkas itu sendiri. Adapun prosedur penataan berkas meliputi:

1) pemeriksaan arsip (inspecting)

2) pengindeksan arsip (indexing)

3) pemberian kode (coding)

4) tunjuk silang (cross refference)

5) penyortiran (sagregating)

6) pelabelan (labeling)

7) penyimpanan berkas (filing)

c. Temu Balik

Kegiatan penemuan kembali arsip didasarkan pada adanya permintaan dari pengguna. Ketepatan dan kelengkapan menemukan kembali arsip sangat tergantung pada sistem pemberkasan yang digunakan. Para pengguna arsip biasanya menyebutkan nama masalah, nama badan, perihal, atau nomor sesuai kepentingannya atau apa yang diingatnya.
4. Penyusutan Arsip

Materi penyusutan arsip meliputi pembahasan mengenai prosedur pemindahan arsip inaktif, pemusnahan arsip, dan penyerahan arsip. Arsip Pemerintah Desa pada hakikatnya merupakan arsip negara yang harus dilakukan pengelolaan sesuai dengan ketentuan yang berlaku. Demikian halnya dengan penyusutan arsip, harus dilakukan sesuai dengan ketentuan yang berlaku di pemerintah daerah kabupaten. Pada prinsipnya arsip inaktif yang memiliki retensi kurang dari 10 tahun dapat dimusnahkan oleh Pemerintah Desa selaku pencipta arsip setelah mendapat persetujuan dari pejabat yang diberi wewenang menurut ketentuan peraturan perundangundangan yang berlaku. Adapun arsip yang memiliki retensi 10 tahun atau lebih setelah memasuki masa inaktif wajib dipindahkan ke lembaga kearsipan kabupaten.

Materi tentang penyusutan arsip ini penting disampaikan di tingkat pemerintah desa karena tidak tertutup kemungkinan pada pemerintah desa terdapat arsip bernilai guna permanen atau arsip statis. Hal ini karena adanya dinamika dalam tata pemerintahan di Indonesia. Di beberapa daerah dilakukan penggabungan beberapa desa (dulu disebut kelurahan) menjadi satu desa (satu kelurahan). Di Kabupaten Bantul Daerah Istimewa Yogyakarta, banyak desa yang merupakan gabungan dari beberapa kelurahan yang ada sebelumnya. Sebagai contoh Desa Sumberagung yang merupakan gabungan antara Kelurahan Bulus, Kelurahan Barongan, dan Kelurahan Sumber. Demikian juga Kecamatan Pleret di Bantul DIY merupakan gabungan antara Kecamatan gondowulung dan Kecamatan Pleret. Contoh yang cukup menarik adalah Kecamatan Imogiri yang merupakan peleburan 
dua kecamatan yang semula merupakan dua wilayah dari dua Provinsi yang berbeda, yaitu Kecamatan Imogiri Yogyakarta (Wilayah Kabupaten Bantul DIY) dengan Kecamatan Imogiri Surakarta (Wilayah Kabupaten Klaten Provinsi jawa Tengah). Adanya dua wilayah yaang berada di tengah-tengah Kabupaten Bantul ini sebagai dampak sejarah Mataram yang dibagi menjadi Kasultanan Yogyakarta dan Kasunan Surakarta yang masing-masing memiliki wilayah di daerah Imogiri. Inilah yang disebut daerah enclave. Daerah enclave juga terdapat di daerah Kotagede, yang semula dibagi menjadi Wilayah Kotagede yogyakarta dan Wilayah Kotagede Surakarta. Perubahan tata pemerintahan ini mesti menciptakan arsip yang memiliki nilai guna statis.

Masih banyak kasus yang memungkinkan pemerintah desa memiliki arsip statis, baik yang berkaitan dengan peran desa pada waktu perjuangan, adanya peristiwa penting, kunjungan pejabat negara, dan kasus penting lain yang memiliki nilai strategis bagi daerah. Terhadap arsip-arsip yang memiliki nilai guna statis, pemerintah desa wajib menyerahkan kepada lembaga kearsipan kabupaten.

Materi pengelolaan arsip dalam Program AMD ini target yang disampaikan meliputi pembuatan naskah dinas, pengurusan surat, penataan dan penggunaan arsip, serta penyusutan arsip. Adapun lingkup yang menjadi obyek AMD adalah arsip yang tercipta pada pemerintah desa/kelurahan, dan Badan Permusyawaratan Desa (BPD), maupun kelurahan.

Secara lebih rinci dalam Program AMD ini tidak mengacu pada tata kearsipan suatu kementerian tetapi memberikan alternatif bagi desa setempat sesuai dengan kondisi yang ada pada desa. Dalam pengurusan surat sarana pencatatan yang digunakan di antaranya kartu kendali, buku agenda, atau sarana lain baik secara manual maupun elektronik disesuaikan dengan kebutuhan desa. Demikian halnya kode klasifikasi, menyesuaikan dengan kode klasifikasi maupun Jadwal Retensi Arsip (JRA) yang berlaku pada Pemerintah Daerah setempat.

\section{Penyelenggaraan Pemerintahan Desa}

Globalisasi yang didukung dengan revolusi di bidang teknologi informasi selain memberikan dampak bagi kecepatan arus informasi juga memberikan kemudahan bagi proses 'pengkopian' kebijakan (Niño-Zarazu' a, Miguel, 20-1-2017). Kebijakan yang diterapkan di suatu negara dengan mudah ditransfer bahkan ditiru oleh negara lain, kebijakan suatu daerah dijiplak daerah lain, atau kebijakan pada bidang tertentu dimodifikasi di bidang lain.

Dalam kaitannya dengan arsip di era global ini, tidak banyak yang menyadari bahwa arsip merupakan kebutuhan hidup bagi manusia. Dapat dikatakan bahwa arsip merupakan kebutuhan dasar hidup manusia yang keempat, selain pangan, sandang, dan papan (Dwi Rokhmatun, Burhanudin, 2012: 11). Dalam berbagai aspek kehidupan, baik sebagai individu maupun institusi, baik dalam lingkup global maupun lokal sama sekali tidak dapat mengabaikan keberadaan arsip.

Sebagai kebutuhan hidup manusia di jaman modern, tentu arsip menjadi komponen yang tidak bisa ditinggalkan untuk berbagai kepentingan. Urusan yang terkait dengan masalah kehidupan bernegara, bermasyarakat, maupun kepentingan bisnis selalu membutuhkan arsip. Artinya arsip akan hadir dalam 
setiap urusan manusia, baik yang berkaitan dengan urusan yang bersifat pribadi, organisasi publik, maupun bisnis.

Kehidupan suatu organisasi senantiasa memerlukan informasi dalam mendukung kinerjanya. Informasi merupakan salah satu sumber data yang memiliki peran strategis bagi sebuah organisasi (Sugiarto, Agus dan Teguh Wahyono, 2005: 7-8). Boone menyebut informasi sebagai "data relevant to the manager in making decision" (Boone, Louis E, 1984: 453). Program AMD secara mendasar sebenarnya merupakan upaya untuk mewujudkan pengelolaan arsip desa secara efektif dan efisien. Program ini dimaksudkan untuk mendorong pemerintahan desa, termasuk kelurahan, untuk mengelola arsip di lingkungan pemerintahan desa sesuai dengan kaidah-kaidah kearsipan dan peraturan perundang-undangan yang berlaku. Lebih mendasar lagi adalah untuk menjamin ketersediaan arsip yang otentik dan terpercaya guna menjamin perlindungan hak-hak keperdataan rakyat. Penyelenggaraan kearsipan pemerintahan desa yang andal merupakan bagian dari penyelenggaraan kearsipan nasional. Hal ini juga untuk mewujudkan penyelenggaraan pemerintahan desa yang baik dan bersih dalam rangka meningkatkan kualitas pelayanan masyarakat. Penyelengggaraan kearsipan secara baik dan benar akan menjamin terwujudnya good governance. Penyelenggaraan tata kearsipan desa yang baik akan mendukung transparansi, memberikan jaminan ketersediaan informasi yang valid, dan akuntabel. Ruh dari good governance adalah menempatkan birokrasi pemerintah sebagai pelayan, sehingga dituntut adanya perubahan orientasi ke arah birokrasi sebagai pelayan publik. (Wicaksono, Kristian Widya, 2006: 51) Keberhasilan transaksi di semua aspek tergantung pada efektivitas manajemen (Ogunlela,
Gabriel Oyebanjo and Lawrence Mpele Lekhanya, 2016).

Pemerintahan Desa dalam hal penyelenggaraan urusan Pemerintahan berdasarkan hak asal-usul desa, urusan pemerintahan yang menjadi kewenangan pemerintah kabupaten yang diserahkan pengaturannya kepada desa, dan tugas pembantuan dari pemerintah, pemerintah provinsi, pemerintah kabupaten/kota serta urusan pemerintahan lainnya yang diserahkan kepada desa. Pelaksanaan kewenangan pemerintahan desa dalam rangka pelaksanaan tugas dan fungsinya merupakan penyelenggara administrasi pemerintahan yang bermuara pada penciptaan berbagai jenis arsip sebagai akibat dari kegiatan yang dilaksanakan. Arsip-arsip tersebut berfungsi sebagai sumber informasi manajemen pemerintahan desa dan merupakan memori kolektif daerah, serta bagian dari memori kolektif bangsa. Sebagai penyelenggara pemerintahan yang memiliki otonomi, pemerintah desa tidak sekedar melaksanakan kebijakan dari penyelenggara pemerintahan yang lebih tinggi, baik pemerintah kabupaten maupun pusat, tetapi juga harus mampu mengintegrasikan kebijakan tersebut dengan kultur yang ada di masyarakatnya. Hal ini karena bagaimanapun antara otonomi dengan kultural memiliki relevansi untuk menciptakan efisiensi dan efektifitas pemerintahan (Kagitcibasi, Cigdem, 2005: 403-422). Harus dipahami bahwa budaya memiliki kaitan dengan budi dan akal manusia (Hutagalung, Nimrot Parasian, dkk, http://ebookinga.com/pdf/jurnalinternasional-tentang-budaya, 14-72016). Artinya kebijakan yang diambil oleh pemerintah harus dapat diintegrasikan dengan budaya masyarakat di mana kebijakan tersebut diterapkan karena akan mempengaruhi kreatifitas dan upaya untuk melaksanakann kebijakan tersebut. 


\section{Permasalahan Desa}

Otonomi daerah yang digulirkan pasca reformasi diharapkan menjadi langkah pembaharuan dalam pelaksanaan pembangunan. Hal ini juga diharapkan mampu memberdayakan potensi daerah, termasuk potensi desa yang ada pada masing-masing daerah. Realitasnya, setelah masyarakat Indonesia berada dalam era otonomi daerah, berbagai problem bermunculan dan implemenasi atas konsep otonomi itu memunculkan banyak konflik baik vertikal maupun horizontal (Malta, Husain, http://jurnal-ekonomi.org/, 13-72016). Tidak sebatas persoalan ekonomi, tetapi pembangunan dari aspek administrasi pemerintahan pada tataran terbawah pun memiliki permasalahan yang terkait dengan kondisi tersebut. Tidak tertutup kemungkinan pada penyelenggaraan pemerintahan desa pun akan dipengaruhi oleh orientasi politik kepala desa apakah sejalan dengan kepala daerah atau tidak. Apabila asumsi ini benar maka ketimpangan antara desa satu dengan yang lain selain di sebabkan oleh potensi desa juga akan lebih diperparah dengan perlakuan yang berbeda karena ketidaksesuaian orientasi politik antara kepala desa dengan kepala daerah.

Berdasarkan gambaran dari uraian tersebut, dimungkinkan bahwa kondisi antara desa satu dengan yang lain akan berbeda-beda. Perbedaan tersebut bukan sebatas sebutan atau jabatan kepala desanya saja tetapi juga menyangkut kondisi geografis, sosial, budaya, ekonomi, dan aspek lainnya. Desa lebih terkonsentrasi untuk wilayah bukan perkotaan, tetapi kondisi geografis, sosial, ekonomi, dan budaya desa akan mempengaruhi penyelenggaraan pemerintahan desa. Kenyataannya ada desa yang memiliki wilayah daerah perkotaan, seperti Desa Caturtunggal di Sleman DIY, wilayahnya meliputi daerah perkotaan di sebelah timur laut Kota
Yogyakarta. Terdapat pusat-pusat bisnis, lembaga pemerintah pusat maupun daerah, dan perguruan-perguruan tinggi besar seperti UGM, UII, UPN, UIN di wilayah Desa Caturtunggal.

Hal tersebut akan lebih terlihat ketika dibanding dengan wilayah desa lain di wilayah Gunung Kidul DIY. Beberapa wilayah desa di Gunung Kidul dapat dikatakan sebagai desa 'miskin'. Bahkan ketika terjadi kekosongan lurah desa, tidak satu pun warga yang berminat melamar menjadi lurah desa. Selain karena kondisi geografisnya merupakan daerah pegunungan yang gersang dan sulit untuk mendapatkan sumber mata air, kondisi sosialnya juga terbelakang. Kondisi ini yang lebih memprihatinkan lagi misalnya di Desa Lapataman Kabupaten Sumenep. Digambarkan oleh petugas arsip dari lembaga kearsipan setempat bahwa desa tersebut sulit dijangkau (Umar, Fatimah, 14-1-2017). Selain itu, gambaran balai desa juga jauh dari gambaran sebuah kantor. Bahkan ketika dilakukan pembinaan dari lembaga kearsipan dilakukan di rumah lurah desa setempat. Arsipnya pun tidak sebanyak yang diperkirakan, apalagi sarana penataan dan penyimpanannya.

Gambaran tersebut akan menjadi sangat tidak berimbang kalau pemetaan dilakukan di desa-desa di Jawa dan di luar Jawa. Antara desa satu dengan desa lain di Jawa dalam berbagai aspek tidak merata. Apalagi dibanding dengan kondisi desa-desa yang ada di pedalaman Kalimantan dan Papua. Jangankan membayangkan gedung balai desa dengan berbagai kelengkapan administrasi atau arsip yang tercipta dari kegiatan penyelenggaraan pemerintahan desa, untuk menuju ke desa yang ada di sana pun tak terbayangkan orang tetap bisa mengenakan pakaian dinas yang lengkap. Medan yang cukup berat, jarak yang jauh, ditambah kemungkinan gangguan di perjalanan adalah gambaran betapa kondisi desa di pedalaman 
Kalimantan dan Papua tidak sebanding dengan yang ada di Jawa.

Gambaran tentang kesenjangan ini perlu dikemukakan bukan dalam rangka menilai kemajuan dan keterbelakangan tetapi sebagai suatu warning bagi program AMD. Artinya Program AMD tidak bisa dipukul rata. Konsep teknis AMD perlu untuk disesuaikan dengan kondisi desa setempat. Peluncuran program dengan konsep 'belakang meja' adalah suatu kekonyolan dan kesia-siaan yang justru akan menimbulkan kesenjangan baru.

Akan berbeda dengan konsep AMD-nya TNI, dapat dilaksanakan untuk desa yang maju, dan dapat pula dilaksanakan untuk desa tertinggal yang akan memberikan manfaat. Tidak perlu konsep yang bertele-tele, karena AMDnya TNI lebih bisa menyesuaikan dengan kondisi desa.

\section{Kendala dalam Pelaksanaan Program AMD}

Negara-negara berkembang, termasuk Indonesia sebagian besar menghadapi masalah terkait dengan administrasi dari transformasi masyarakatnya. Transformasi ke arah kemajuan, kemakmuran, keadilan, dan partisipasi. Hal ini terkait dengan pelaksanaan pembangunan terutama masalah administrasi negara (Tjokroamidjojo, Bintoro dan Mustopadidjaja AR., 1984: 89). Alasannya adalah karena hal ini lebih bersifat praktis yaitu negara menjadi pemegang otoritas sekaligus wadah dari unsur-unsur modern dalam masyarakat. Konteks ini diasumsikan bahwa sebagian besar masyarakat negara-negara berkembang masih merupakan masyarakat tradisional serta unsur-unsur modern nonpemerintah masih sedikit jumlahnya. Keadaaan demikian, aparatur negara berperan sebagai alat utama dalam mengelola atau sebagai administrator dalam usaha-usaha pembangunan. Faktor penentu keberhasilan pembangunan nasional terletak pada kemampuan aparaturnya. Kondisi ini berlaku dari aparatur pemerintah tingkat pusat sampai aparatur desa. Dapat dikatakan bahwa bila aparaturnya handal maka akan membawa kemajuan pada sektor di lokasi tersebut.

Aparatur desa merupakan intisari dari potensi Sumber Daya Manusia (SDM) pada desa, sekaligus representasi sosial-budaya masyarakatnya. Tingkat pendidikan, pola pikir, etos kerja, serta tradisi yang melingkupinya akan direpresentasikan pada aparatur desa. Kondisi ini akan mempengaruhi pelaksanaan AMD. Apalagi program ini lebih banyak berkaitan dengan pengelolaan catatan dan rekaman dari proses administrasi negara pada tingkat paling bawah yang menjadi titik lemah dalam proses pembangunan nasional secara keseluruhan.

Mewujudkan pengelolaan arsip yang sistemik bukan persoalan mudah. Selain faktor aparaturnya, sebenarnya permasalahan yang dihadapi dalam program AMD ini bersumber pada ketidakmerataan potensi, kondisi, dan sumber daya yang dimiliki Pemerintah Desa. Apabila program ini diperlakukan secara nasional dalam standar yang sama, maka permasalahan tersebut akan semakin rumit. Kesenjangan potensi, kondisi, maupun sumber daya yang ada antara desa-desa yang ada di Jawa dengan yang ada di luar Jawa, khususnya pulau-pulau terpencil. Demikian juga apabila dibandingkan dengan kelurahan, yang relatif berada di wilayah perkotaan.

Kondisi Balai Desa sebagai 'ibukota' Desa di Indonesia dapat dikatakaan sebagian besar di bawah ratarata. Untuk pemerintah desa yang kondisinya berada di atas rata-rata, apapun bentuk program AMD relatif dapat memberikan respon positif terhadap program AMD. Akan tetapi bagi desa yang berada pada garis rata-rata atau bahkan di bawah rata-rata menakar 
keberhasilan program AMD sama dengan mengharap 'tumbuhnya jamur di musim kemarau'. Ketidakmerataan ini bukan hanya menyangkut satu aspek dalam penyelenggaraan pemerintahan desa tetapi menyangkut berbagai aspek.

SDM desa dari kepala desa, sekretaris desa, hingga perangkat lain lebih cenderung menjadi sosok yang lebih mengedepankan kewibawaan dibanding kompetensi teknis. Sekalipun basis pendidikan telah disyaratkan untuk memangku jabatan tersebut tetapi banyak juga yang tidak memenuhi persyaratan tersebut. Hal ini berbeda kasus untuk desa-desa yang berada di Pulau Jawa. Aspek SDM tidak dapat diukur dari satu sisi semata tetapi hal-hal yang berkaitan dengan wawasan dan motivasi akan mempengaruhi pola pikir mereka. Kebersahajaan, jiwa gotong-royong, kejujuran, dan sikap saling percaya masyarakat desa menjadi kekayaan berharga mereka. Di sisi lain, hal tersebut dapat menjadi sesuatu yang kontraproduktif apabila dikaitkan dengan administrasi modern yang senantiasa akrab dengan catat-mencatat. Sikap bersahaja, jiwa gotong-royong, serta sikap saling mempercayai dalam pola kehidupan masyarakat desa cenderung mengabaikan bukti-bukti tertulis. Transaksi yang dilakukan dalam kehidupan pemerintah desa kadang diwarnai kondisi tersebut. Kewibawaan yang dimiliki oleh pimpinan desa kadang menyebabkan masyarakat desa menjadi pihak yang tidak berdaya untuk menuntut bukti tertulis dalam pelaksanaan urusan pemerintah desa.

Aspek lain yang mempengaruhi pola penyelenggaraan pemerintahan desa adalah motivasi untuk menerima perubahan. Kemapanan yang mereka rasakan menjadikan kehidupan mereka berada dalam kondisi yang relatif tenteram. Kondisi ini menempatkan penyelenggaraan pemerintahan desa sebagai rutinitas serta status quo. Artinya, apa yang setiap hari harus dihadapi oleh kepala desa berikut para aparat desa adalah tugas rutin yang memiliki pola yang sama dari hari ke hari. Demikian juga masyarakat memahaminya dalam pengertian yang tidak jauh berbeda. Pada kondisi ini, penyelenggaraan tata kearsipan akan mengalami kendala. Selain pada aspek penciptaan, perubahan pada aspek sistem tidak mudah untuk dilakukan. Keengganan beralih dari status quo ke tata kearsipan yang lebih berbasis pada sistem dianggap sebagai suatu beban. Hal ini akan lebih rumit ketika dihadapkan pada suatu kenyataan bahwa di lingkup pemerintahan desa memiliki SDM yang sangat terbatas, baik dari segi kuantitas maupun kualitas.

Pelaksanaan Program AMD bagimanapun sederhananya membutuhkan SDM. Dari segi kuantitas desa memiliki SDM yang sangat terbatas. Hal ini terkait dengan kemampuan desa untuk menggaji karyawan. Banyak desa yang memberikan gaji bagi para aparatnya maupun karyawannya dengan tanah kas desa. Oleh karena itu, untuk mengangkat karyawan mesti mempertimbangkan kemampuan desa. Oleh karena itu, karyawan di lingkungan pemerintah desa sangat terbatas. Bisa jadi tidak setiap kepala bagian memiliki staf.

Kondisi lain yang berpotensi menjadi kendala bagi pelaksanaan AMD adalah ketidaksamarataan kemampuan anggaran. Seperti diketahui bahwa penyelengggaraan pemerintahan desa dilaksanakan dengan biaya Anggaran Pendapatan dan Belanja Desa (APB Des). Sekalipun tidak tertutup kemungkinan adanya anggaran lain, baik APBD, APBN, dana hibah dan sebagainya, tetapi diasumsikan bahwa desa membiayai dirinya sendiri. Aspek kemampuan keuangan akan menjadi tolok ukur keberhasilan suatu program. Bagi desa-desa yang termasuk 'desa kaya' atau desa yang memiliki kemampuan di atas rata-rata program 
apapun yang dilaksanakan pemerintah tidak akan menjadi beban. Bagi desadesa yang berada di bawah garis ratarata, kegiatan di luar pelaksanaan tugas rutin menjadi beban.

Program AMD merupakan program yang memerlukan pembiayaan. Arsip Nasional RI sebagai pemilik program sebatas meluncurkan program berikut pelatihan yang diperlukan, tidak sepenuhnya disertai dengan perlengkapan lain yang dibutuhkan. Berbagai sarana yang dibutuhkaan untuk menunjang keberhasilan program ini hanya sedikit yang dipenuhi oleh ANRI. Demikian juga dengan lembaga kearsipan provinsi maupun kabupaten memberikan bantuan yang bersifat stimulan. Berbagai kelengkapan yang diperlukan selanjutnya menjadi beban bagi desa yang bersangkutan. Sekalipun tidak dalam jumlah yang besar tetapi bagi desa tertentu hal ini dianggap sebagai beban. Artinya program AMD hanya akan dapat diselenggarakan di desa-desa yang berkemampuan terbatas di awal tahun penyelenggaraan (tidak berkelanjutan).

Kemampuan keuangan erat kaitannya dengan keterbatasan kemampuan untuk memenuhi kebutuhan prasarana dan sarana. Desa-desa di daerah maju secara sosial dan ekonomi, pemenuhan kebutuhan sarana kearsipan seperti filing cabinet, rak, boks arsip, map, penyekat, bahkan perangkat komputer bukan menjadi kendala. Sebaliknya, bagi desa-desa yang hanya mengandalkan hasil bumi hal tersebut pengadaan sarana-sarana tersebut menjadi masalah. Hal yang lebih memprihatinkan lagi adalah ketidakadaan ruangan. Banyak pemerintah desa yang memiliki ruang kerja bagi para aparatur desa yang sangat terbatas sehingga tidak bisa menyediakan ruang untuk pengelolaan arsip. Keterbatasan mencakup berbagai aspek. Banyak desa yang dibangun dengan menggunakan bahan bangunan seadanya, bahkan menggunakan bahan-bahan yang diperoleh dari desa mereka. Hal ini ditambah dengan arsitektur bangunan yang tidak memiliki konsep, lantai tidak disemen, dinding dari tumbuh-tumbuhan, serta atap yang bersifat ala kadarnya.

Kendala aspek administrasi dapat dikatakan bahwa penyelenggaraan pemerintahan desa lebih cenderung pada status quo. Artinya, apa yang mereka kerjakan selama ini akan diterapkan dan diwariskan pada generasi berikutnya. Bekerja secara sistemik dianggap sebagai sesuai yang akan membebani mereka. hal-hal di luar yang memang prinsipil sangat sedikit perubahan yang dilaksanakan. Kondisi semacam ini tentu tidak kondusif bagi program AMD. Jangankan sistemnya, terhadap arsipnya pun mereka tidak meletakkan sebagai sesuatu yang cukup penting.

Selain kendala tersebut, kondisi riil pengelolaan arsip di desa juga perlu untuk dikemukakan. Hal ini menjadi dasar bagi upaya mengadakan perubahan terhadap sistem yang berlaku pada saat itu.

1. Pengendalian surat

Selama ini yang lazim digunakan untuk pengendalian surat di lingkungan pemerintah desa adalah buku agenda. Surat dicatat berulangkali, baik di sekretariat maupun pada masing-masing bagian. Model agendanya sangat sederhana, dengan tidak disertai kode klasifikasi maupun indeks surat maupun indeks berkasnya. Buku agenda juga digunakan sebagai buku ekspedisi.

2. Penyimpanan Arsip

Hampir tidak ada sistem dalam penyimpanan arsip di kebanyakan pemerintah desa. Hanya pada pemerintah desa yang memang telah memperhatikan bidang kearsipan yang menerapkan sistem penyimpanan arsip. Mayoritas pemerintah desa penyimpanan berkasnya tidak ada sistem tertentu yang ditentukan. Mereka meletakkan 
arsip di atas meja kerja. Arsip tersebut ketika telah selesai digunakan kemudian dipindahkan ke gudang. Gudang ini bukan gudang arsip tetapi gudang yang berisi berbagai barang yang perlu disimpan. Pengecualian untuk arsip yang dianggap arsip vital, terutama arsip-arsip tanah dan arsip keuangan. Terhadap arsip ini pemerintah desa memperlakukan sebagai arsip yang perlu disimpan secara khusus. Arsip tersebut tidak disimpan menjadi satu dengan arsip lain tetapi disimpan di lemari tersendiri. Jangan diasumsikan dengan lemari khusus yang memiliki tiingkat keamanan yang cukup tinggi. Lemari kayu yang cukup tua dengan sistem pengamanan yang sangat sederhana adalah tempat khusus yang kebanyakann digunakan untuk menyimpan arsip-arsip bernilai guna vital ini.

3. Penyusutan

Bagi kebanyakan pemerintah desa istilah penyusutan identik dengan pemusnahan arsip. Tidak ada sistem maupun prosedur yang diperlukan dalam kegiatan penyusutan arsip yang mereka lakukan. Satu-satunya pertimbangan yang digunakan adalah arsip yang dimusnahkan tidak diperlukan lagi dalam kegiatan pemerintah serta pemanfaatan ruangan. Walaupun demikian kebanyakan juga tidak serta merta memusnahkan arsip yang tidak lagi mereka gunakan.

Kendala program AMD bukan hanya dari aspek obyek AMD tetapi juga lembaga pembina. Apabila program ini hanya bergantung pada Arsip Nasional RI (ANRI) maka ANRI akan 'kehabisan energi', sedangkan lembaga kearsipan daerah yang ada belum memiliki sumber daya yang merata. Apabila dipaksakan hal ini justru akan menjauhkan program ini dari keberhasilan. Artinya, dengan kondisi yang ada saat ini apabila lembaga kearsipan daerah dipaksa untuk melaksanakan program ini akan banyak mengalami kendala, sekalipun mereka sudah mengikuti pendidikan dan latihan. Keterbatasan SDM, sarana, dan anggaran adalah kendala yang memiliki kemungkinan kuat untuk menghambat keberhasilan program ini.

\section{Alternatif Pemecahan Masalahan}

Berdasarkan permasalahanpermasalahan di atas maka dapat disimpulkan bahwa untuk melaksanakan program AMD tidak bisa dilakukan dengan pola 'pukul rata'. Strategi dan materi yang digunakan dalam program AMD mesti harus disesuaikan dengan kondisi desa yanng menjadi sasaran program AMD. Tujuan program AMD adalah sebagai upaya penyelamatan arsip dari tingkat grassrood sehingga pelaksanaan program ini perencanaan yang matang. Konsep yang jelas, strategi yang tepat, materi yang sesuai kebutuhan menjadi kunci keberhasilan program ini. Beberapa langkah alternatif yang mesti harus dilakukan terkait dengan hal tersebut adalah:

1. Perumusan konsep secara jelas

Peluncuran suatu program kerja seperti Program AMD ibarat seperti persiapan perang. Memenangkan pertempuran tidak cukup hanya ditopang kecanggihan senjata, atau hanya kehandalan tentara, tetapi berbagai aspek akan saling memberi kontribusi bagi keberhasilan untuk memenangkan pertempuran. Berdasarkan asumsi tersebut maka dalam pelaksanaan Program AMD perlu dirumuskan secara matang halhal yang terkait dengan program tersebut. Konsep harus dirumuskan secara jelas, mulai dari perencanaan, perorganisasian, pelaksanaan, dan evaluasi/pengawasan. Konsep yang dirumuskan perlu memperhatikan kondisi riil di lapangan. Tanpa konsep yang jelas program ini tidak akan berjalan maksimal, bahkan akan 
menjadikan dunia kearsipan dalam penyelenggaraan pemerintahan desa semakin terpinggirkan dan menjadi beban.

2. Pemetaan

Bergerak di medan pertempuran mmemerlukan peta agar penyerangan dapat dilakukan secara tepat, baik sasaran maupun kekuatan yang diperlukan. Demikian halnya dengan pelaksanaan Program AMD. Indikasi adanya ketidakmerataan kondisi desa yang cenderung tidak berimbang maka perlu adanya langkah pemetaan. Pemetaan ini diperlukan untuk merumuskan klasifikasi desa yang menjadi sasaran program. Dengan pemetaan ini maka dapat dilakukan model sosialisasi maaupun bimbingan teknis secara tepat. Desa yang masuk dalam kondisi sangat memadai tidak akan disamakan dengan desa yang memiliki kondisi sangat tidak memadai.

Selain pengklasifikasian desa sesuai dengan kondisinya diperlukan juga pembakuan paket Program Pembinaannya. Dalam hal ini masingmasing klasifikasi desa diberikan paket pembinaan sesuai dengan klasifikasinya. Paket pembinaan ini dibuat berbeda-beda disesuaikan dengan kondisi pada masing-masing klasifikasi desa.

Untuk keperluan ini, dapat diklasifikasikan menjadi empat kelompok desa yang sesuai dengan kondisi masing-masing. Hal ini dapat dilakukan oleh lembaga kearsipan kabupaten/ kota yang lebih mengetahui kondisi desa di wilayahnya. Dalam rangka pemetaan ini dapat diklasifikasikan menjadi empat, yaitu :

a. Desa Klasifikasi A

Desa yang masuk klasifkasi A adalah desa yang benar-benar memiliki sumber daya yang mandiri, baik yang menyangkut SDM, anggaran, prasarana dan sarana, dan kesiapan sistem. Kemandirian ini diperlukan, selain akan memberikan kemudaahan dalam sosialisasi hal yang jauh lebih penting adalah keberlanjutan dari program ini. Kriteria kemandirian ini dapat dirumuskan oleh lembaga kearsipan daerah. Dari SDM disyaratkan bagi desa yang memiliki petugas arsip secara khusus dan dengan basis pendidikan petugas setidaktidaknya SMA. Selanjutnya dari aspek anggaran desa yang masuk klasifikasi A adalah desa yang dapat menganggarkan secara khusus untuk bidang kearsipan. Adapun dari ketersediaan prasarana dan sarana, desa yang masuk klasifikasi A adalah desa yang memiliki ruang yang dapat digunakan secara khusus untuk ruang simpan arsip serta memiliki kemampuan untuk memenuhi kebutuhan sarana. Hal yang tidak bisa diabaikan adalah adanya sistem administrasi kearsipan yang telah dilaksanakan di desa yang bersangkutan. Apapun sistem yang ada, setidak-tidaknya menjadi embrio bagi pelaksanaan sistem selanjutnya. Termasuk klasifikasi ini adalah kantor lurah. Hal ini menjadi pertimbangan karena kelurahan cenderung terletak di wilayah perkotaan.

Selain dari kondisi desanya, desa yang masuk klasifikasi A dapat dilaksanakan Program AMD Paket 1. Pada paket 1 selain menekankan pengelolaan arsip secara sistemik, juga dikenalkan kearsipan dengan basis teknologi informasi.

b. Desa Klasifikasi B

Untuk klasifikasi ini
dikelompokkan desa yang
memiliki tempat yang dapat
dijadikan ruang simpan arsip,
tidak memiliki sarana kearsipan,


$\begin{array}{lrr}\text { dan terbatas } & \text { SDM-nya. } \\ \text { Keterbatasan ini } & \text { tidak } \\ \text { menghambat } & \text { bagi } & \text { upaya }\end{array}$ peningkatan pengelolaan arsip dengan suatu catatan tugas ini dapat disampirkan pada SDM yang ada. Klasifikasi ini diberikan materi paket 3 yang menekankan pada upaya pengelolaan arsip secara sistemik, serta stimulan sarana.

c. Desa Klasifikasi C

Desa yang masuk ke klasifikasi $\mathrm{C}$ adalah desa yang memiliki ruang kerja terbatas, tidak memiliki sarana kearsipan sama sekali, dan SDM terbatas yang tidak memungkinkan untuk disampiri tugas lain. Pada klasifikasi ini diberikan paket 3 yang lebih menekankan pada materi teknis yang benar-benar aplikatif, seperti pencatatan surat serta penataan berkas secara benar.

d. Desa Klasifikasi D.

Untuk klasifikasi ini dimasukkan desa yang sama sekali tidak memiliki sumber daya yang memadai. Ruang kerja aparat tidak memadai, sarana tidak memadai, dan kekurangan SDM. Untuk klasifikasi terakhir hal yang perlu dilakukan dalam program Arsip Masuk Desa paket 4 yang lebih menekankan sosialisasi serta penanaman pemahaman akan arti penting arsip.

3. Penyiapan Sumber Daya

Setelah dilakukan pemetaan langkah berikutnya adalah penyiapan sumber daya, baik yang terkait dengan personil, anggaran yang dibutuhkan, sarana, maupun panduan yang dibutuhkan. Persiapan ini sudah tentu mesti harus disesuaikan dengan hasil pemetaan yang telah dilakukan. Pada langkah ini juga disiapkan penjadwalan yang tepat sehingga meminimalisasi kemungkinan terjadinya penumpukan kegiatan, ketimpangan sasaran,

ketidakmerataan, serta ketidaktepatan.

a. Sumber Daya Manusia (SDM)

SDM pembina yang akan melaksanakan kegiatan Program AMD harus disiapkan dengan baik. SDM yang ditempatkan bukan sekedar dibagi atas dasar pemerataan tugas tetapi harus dipertimbangkan jumlah personil, waktu yang dibutuhkan, kemampuan personil, serta desa sasaran yang akan menjadi sasaran Program AMD. Pola penjadwalan tidak hanya atas dasar pemerataan tugas, apalagi pemerataan honorarium. Program AMD memerlukan perhitungan dari berbagai aspek secara cermat. Bukan hanya aspek teknis tetapi juga kemampuan SDM untuk dapat memahami sosiologi serta kultur masyarakat desa yang akan menjadi sasaran. Ketidakmampuan SDM menyesuaikan dengan sosilkultural masyarakat desa maka dapat diibaratkan "naik perahu di atas pegunungan". Komunikasi dengan masyarakat desa, terutama yang berada di daerah kawasan pedesaan, tidak sekedar menyangkut kecanggihan berorasi. Kemampuan memahami dan menyesuaikan dengan budaya desa yang bersangkutan akan menjadi sarana yang sangat efektif bagi keberhasilan program ini. Masyarakat desa, termasuk aparatur desa, yang relatif bersahaja tentu akan menunjukkan penolakannya apabila disuguhi hal-hal yang bersifat demonstratif, teoritis, dan eksklusif. Gambaran, contoh, ataupun hal-hal yang setiap hari mereka alami lebih bisa diterima daripada disuguhi hal-hal yang asing bagi mereka. 
Demikian juga yang terkait dengan psikologi sosial masyarakat desa harus menjadi bekal bagi personil yang akan terjun ke desa. Sikap menggurui, serta menempatkan mereka sebagai obyek, mereka sama sekali tidak akan menentang tetapi tidak akan mendapat respon yang baik.

b. Anggaran

Bagi petugas yang akan melaksanakan Program Arsip Masuk Desa tentu tidak cukup dibekali hal-hal yang bersifat teknis di bidang kearsipan. Penyiapan logistik, baik yang terkait dengan operasional program maupun kotra prestasi bagi personil yang melaksanakan kegiatan ini perlu disiapkan secara matang. Dalam hal ini perlu dipertimbangkan antara anggaran yang tersedia dengan rencana kegiatan secara keseluruhan.

Hal paling mendasar dalam menunjang AMD adalah membangun SDM. Manusia menjadi aktor utama dalam pembangunan nasional. Oleh karena itu, hal pertama yang harus dibangun adalah SDM. Pembangunan SDM dapat dilakukan melalui pendidikan. Pendidikan diharapkan mampu menghasilkan SDM yang akan menjadi agent of change. (Syah, Muhibbin, 1995) Pendidikan yang dimaksud adalah pendidikan yang benar-benar meletakkan dasar pemikiran yang berorientasi untuk mampu mengadakan perubahan secara kultural, bukan sekedar tempat memperoleh gelar dan status.

Dalam rangka melakukan langkah 'revolusioner' dalam mewujudkan reformasi birokrasi desa diperlukan seorang kepala desa yang benar-benar mampu menjadi seorang pemimpin yang

\begin{abstract}
memiliki kharisma, bersih, kemauan keras untuk menumbuhkan needs for achievement, visioner, dan bukan partisan. Tanpa pemimpin yang memenuhi kriteria tersebut sulit untuk melakukan perubahan. Secara teoritis pemimpin tidak dapat dibentuk atau dilahirkan tetapi pemimpin adalah anak jaman. Menurut Sugeng pemimpin yang demikian kadang tidak diketahui keberadaannya. (Sugeng, 2016) Dalam hal ini yang disebut dengan seorang pemimpin adalah pemberi semangat (encourager), motivator, inspirator, dan dinamisator. (Sugeng, Y, 2007)
\end{abstract}

\section{KESIMPULAN}

Program AMD merupakan program yang memiliki arti strategis bagi penyelamatan arsip di masa depan. Selain itu juga memiliki arti penting bagi pengelolaan arsip yang berdayaguna dan berhasilguna. Ini merupakan upaya antisipasi terhadap dinamika masyarakat yang semakin kompleks. Kompleksitas permasalahan yang muncul akibat dari perkembangan kehidupan berbangsa, bernegara, dan bermasyarakat menuntut ketersediaan arsip yang cepat, tepat, dan lengkap. Program ini juga sebagai upaya mengejar ketertinggalan dalam pengelolaan administrasi negara, khususnya pada tataran paling bawah. Hal ini dikarenakan secara prinsip program arsip masuk desa adalah upaya modernisasi pengelolaan pilar utama dalam pelaksanaan administrasi negara berupa catatan atau rekaman kegiatan dalam bentuk arsip. Secara tidak langsung hal ini juga merupakan langkah dalam menjaga keutuhan kedaulatan negara.

AMD sebagai program yang memiliki arti strategis tidak dapat dilaksanakan secara optimal sehingga 
menjelma menjadi kegiatan yang kurang efektif. Kejelasan konsep, pemetaan terhadap kondisi desa yang ada di tanah air, kesiapan sumber daya manusia, anggaran, sarana, maupun metode akan menjadi komponen penentu kesinambungan program ini. Kendala yang dihadapi dalam implementasi Program AMD bersumber pada ketidakmerataan potensi, kondisi, dan sumber daya, antara lain kesenjangan antar desa yang dimiliki Pemerintah Desa di bidang anggaran dan SDM, perbedaan sosial budaya. Alternatif solusi yang dapat dilaksanakan dalam implementasi Program AMD antara lain perumusan konsep yang jelas, pemetaan kondisi dan sumber daya desa, serta penyiapan SDM dan anggaran.

\section{DAFTAR PUSTAKA}

Ashiddiqie, Jimly, 2010, "Perkembangan dan Konsolidasi Lembaga Negara pasca Reformasi”. Jakarta: Sinar Grafika.

Boone, Louis E., 1984, "Principle of Management”. New York: Random House.

Fadhillah, Khoerun Nisa, "Pembangunan Kearsipan Dalam Kerangka Otonomi Daerah di Indonesia", Jurnal Kearsipan, Vol. 7, 2012, http://www.anri.go.id/assets/do wnload/ jurnal kearsipan Jurnal-Vol-72012.pdf, diunduh tanggal 21-12017, pukul 08.16.

Fergiyono, Nico. "Ciri-ciri Desa dan Kota", http://nicofergiyono.blogspot.co .id/2014/06/ciri-ciri-desakota.html, diunduh tanggal 21-12017, pukul 08.05.
Hutagalung, Nimrot Parasian, dkk. "Globalisasi Budaya Ditengah Masalah Identitas Nasional”, http://ebookinga.com/pdf/jurnalinternasional-tentang-budaya, diakses tanggal 14-7-2016, pukul 12.07.

Kagitcibasi, Cigdem, "Autonomy and Relatedness in Cultural Context, Implications for Selt and Family", Journal Of CrossCultural Psychology, Vol. 36 No. 4, July 2005 403-422 DOI: 10.1177/0022022105275959, http://jcc.sagepub.com/, diakses tanggal 24-1-2017, pukul 11.30

Malta, Husain "Konglomareasi Internasional”, http://jurnalekonomi.org/ diakses tanggal 13-7-2016 pukul 11.05.

Martono, Budi, 1994, "Penataan Berkas dalam Manajemen Kearsipan”. Jakarta: Sinar Harapan.

Miguel Nin o-Zarazu' a, "Aid, Education Policy, And Development", https://www.journals.elsevier.co m/international-journal-ofeducational-development/mostdownloaded-articles, diunduh tanggal 20-1-2017, jam 23.10.

Ogunlela, Gabriel Oyebanjo and Lawrence Mpele Lekhanya, "Problems and Perspectives in Management, Volume 14, Issue 1, 2016, http://businessperspectives.org/, diakses tanggal 13-7-2016 pukul 10.40 .

Perna, Laura W., Kata Orosz, dan Zakir Jumakulov, "Understanding the human capital benefits of a government-funded

international scholarship program: An exploration of Kazakhstan's Bolashak program" International Journal of Educational Development, 
http://www.sciencedirect.com/sc ience/article/pii/S073805931500 0528 diunduh tanggal 27-12017, pukul 00.05.

Rokhmatun, Burhanudin Dwi, 2012, "Profesi Kearsipan, Memahami Profesi Kearsipan, karakteristik dan Syarat, Ketrampilan dan Pengetahuan, Kompetensi dan Kode etik Arsiparis”. Yogyakarta: Panduan.

Sasrawan, Hedi. "Pengertian Desa", http://hedisasrawan.blogspot.co. id/2016/01/pengertian-desaartikel-lengkap.html?m=1, diunduh tanggal 20-01-2017, pukul 20.00.

Simamora, Janpatar, "Reformasi Birokrasi, Good Governance dan Etika Pelayanan Publik" Jurnal Ilmu Administrasi STIA LAN Bandung Volume $\mathrm{X}$ Nomor 1 Tahun 2013.

Soedjatmoko, 1980, "Kesadaran Sejarah dan Pembangunan", dalam Soemartini, ed. Arsip dan Sejarah, Jakarta: Arsip Nasional RI.

Sudrajat, Tatang. "Konteks Politik Penataan Kelembagaan Negara“, Jurnal Ilmu Administrasi Media Pengembangan dan Praktik Administrasi Volume XIII Nomor 1 April 2016.

Sugeng, 2016, "Peran Kepemimpinan Aparatur Pemerintah dalam Rangka Mewujudkan Kepemerintahan yang baik, Good Governance”, Materi Orasi Ilmiah pada Wisuda Sarjana S1 STISIP Kartika Bangsa yang tidak diterbitkan. Yogyakarta.
Sugeng, Y., 2007, "Manajemen Sumber Daya Manusia". Malang: Universitas Widya Gama.

Sugiarto, Agus dan Teguh Wahyono, 2005, "Manajemen Kearsipan Modern”.

Tjokroamidjojo, Bintoro dan Mustopadidjaja AR., 1984, "Teori dan Strategi Pembangunan Nasional”. Jakarta: Gunung Agung.

Wicaksono, Kristian Widya, 2006, "Administrasi dan Birokrasi Pemerintah". Yogyakarta: Graha Ilmu.

http://stialanbandung.ac.id/index.php?op $\underline{\text { tion }=\text { com_content } \& \text { view }=\text { article }}$ \&id=748: konteks-politikpenataan-kelembagaannegara\&catid $=70$ :volume-xiiino1-tahun-2016\&Itemid=63, diunduh 24-1-2017, pukul 22.15.

https://id.wikipedia.org/wiki/Desa, diunduh tanggal 20-1-2017 pukul 20.10.

\section{Wawancara:}

Wawancara dengan Fatimah Umar, pegawai Kantor Perpustakaan dan Arsip Daerah Kabupaten Sumenep Provinsi Jawa Timur, 14 Januari 2017. 